\title{
Recent Development in Public Finance Since the 2008-2009 Global Crisis
}

\author{
Hale Balseven \\ Faculty of Economics and Administrative Sciences, Akdeniz University, Turkey
}

Copyright $\subset 2016$ by authors, all rights reserved. Authors agree that this article remains permanently open access under the terms of the Creative Commons Attribution License 4.0 International License

\begin{abstract}
The 2007/2008 global crisis has put into agenda a basic debate in the field of public finance in what concerns state intervention. The crisis shows the narrowness and inadequacy of current mainstream and neoclassical approaches related to subjects such as the specific forms of state intervention during the crisis as well as its origins and causes. None of these approaches perceive state intervention as an economic and social reality of the discipline of public finance. Although they provide some insightful discussions on the financial crisis, they remain essentially descriptive. New developments after the global crisis revealed spectacular alternative views by reinterpreting the forms of state intervention in economic theory as well as its applications in specific countries. In these views the state and its policies are determined and transformed socially, politically and historically. In this respect, we need to know more about the dynamics of the capitalist system, its economic institutions and the patterns of production relations in every conjuncture of economic history as well as the functioning of financial systems. This paper argues that the field of public finance is socially determined as any other scientific practice. Following the recent discussions in theory and its applications, this paper treats state intervention as both a "symptom" and a "cause" of critical changes in economy and society.
\end{abstract}

Keywords Public Finance, State Intervention, Economic Methodology, Neoclassical Economics

\section{Introduction}

"..So economics limp along with one foot in untested hypotheses and the other in untestable slogans. Here our task is to sort out as best we may this mixture of ideology and science. We shall find no neat answers to the questions that it raises. The leading characteristic of the ideology that dominates our society today is its extreme confusion. To understand it means only reveals its contradictions."

Joan Robinson, [1]
Following the 1920's and 1970's, the global crisis of 2008 has started once again a discussion on the explanatory power of modern economics as a discipline $[2,3,4]$. The issue that came out during this process was that the discipline extremely condensed on formal modelling in the framework of a single approach. During this period, the explanatory power of hypothetical and minimalist models on economic reality has not only been examined by prominent economic theorists but also by policy implementers. The models at issue which form the basis of modern economics are the configurations of the main assumptions of classical economics that are not so new, brought up to the agenda by neoclassical economics such as homo economicus, the efficient market hypothesis, the equilibrium paradigm.

On the other hand, the economic effectiveness of the state has created a new discussion that has been brought forward during the post-crisis period [5]. The discipline of public finance, which constitutes the specific area of economics concerning the economic effectiveness of the state, has been conceived as a field limited to market intervention in the neoclassical theory. However the state intervention reached a level much beyond the limits of neoclassical economics during the global crisis. Thus, different theories and approaches related to the reasons, forms and consequences of state market intervention during the post-crisis period have gained even more importance.

The 1920's and 1970's have been periods when similar discussions have come to the forefront in the discipline of economics. Especially during the 1950's discussions on the methodology of economics have been made, in which students in economics also participated. Those discussions concerned the multiplicity of theories which rejected the $a$ priori analysis and which had not passed the test in the theory of economics and economic sciences [6]. What differentiates the post-2008 era from these periods is that initiatives have been taken by mainly students, with the aim of making a more "accurate" definition of the economic reality. In 2010, students who criticized the education in economics in France have launched the post-autistic economics movement. This movement turned out into an international student movement for multivocality in 
economics and a portal named the Real World Economic Review, which also brought together academicians, has been established.

Especially since the global crisis, discussions that can be followed up from the economic literature as well as from academic publications are questioning how the discipline of Economics could provide a better set of tools for explaining the economic reality. Is it possible to enhance the restraining set of concepts and theories related to the facts defined with the formal models that are being criticized? Was this always so? If not, which historical conditions led to this result? It is a fact that considerable academic literature has been developed by academics since 1980s for answering these questions $[4,6,7,8]$.

This paper will pay special attention to the particular contradiction on the role of the states which revealed in global crisis. Although neoclassical theory defines state as a non-economy, we experienced wide the state interventions for responding to the downturn in the global crisis both in the U.S.A and EU. The paper argues that it is impossible to understand the role of the state without laying bare the dimensions in shaping of state with the structure of economic, social and political. First of all, approaches criticizing the neoclassical theory of economics are being explained generally. Secondly, the possible alternatives of Neoclassical economics are being discussed generally in the framework of the discipline of economics and specifically in the context of the discipline of public finance.

\section{Debates within the Discipline of Economics/Public Finance Following the Global Crisis}

For a long time, economists have argued that approaches of modern academic economics have been rendered attractive with illusive/symbolical/fictional concepts (rational expectations, representative agent) that have been widely adopted [9]. Common theoretical assumptions have been influential as a determiner for shaping the economic environment in policy practices and in the developments of the world economy.

Especially, the theoretical and conceptual base provided by financial economics has ensured the growth and proliferation of financial services which played an important role during the global crisis. The most determinant theory of this theoretical base is the efficient market hypothesis developed by E. Fama [10] in the middle of the 1960's. The market defined by the hypothesis is the perfect competition market of neoclassical economics. The hypothesis and the models developed on it have created a new situation. If no market actor has the ability to obtain a profit above the average and if a systematic "insider trader" is not possible, it is not necessary to make any state regulation in markets; because these interventions would only prevent the autoregulation capacity of the market. The interesting conceptual framework offered by the efficient market hypothesis has not only kept the market regulation at the minimum level, but also it has led to the absence of regulation in financial instruments such as derivatives, which played a significant role in provoking the crisis.

In fact, Post-Keynesian economists have revealed long ago that the explanatory power of reductionist concepts related to financial markets was very limited. Post-Keynesian monetarist economist H. Minsky [11] has written that financial capitalism was essentially prone to instability and crisis due to speculations made over the growing debt (Financial Instability Thesis). This approach reveals the importance of state intervention and regulation in financial stability as well as in the prevention of crises. Post-Keynesian approaches concerning the market intervention of the state through public finance instruments and market regulation have not been reflected in practices, they have not gone beyond creating weak discussions except crises and instability periods.

The developments which have come to the forefront in the discipline of economics/finance after the crisis might be summarized under the following headings:

\subsection{Developments within Neoclassical Economics}

As neoclassical theory was criticized for adhering to an idealized model of perfectly competitive markets, the major extensions of the neoclassical approach has been in market imperfections, new theories of human behaviour and of equilibrium. However, "they all continue to refer to the traditional neoclassical approach as their basic benchmark. They construct their approaches to the economy with the aim of determining the conditions under which the diverse interest of individuals are or can be harmoniously reconciled" [4].

For example, when the faith in informationally efficient markets has been lost, some economists tended towards behavioural finance. The radical market tendency did not disappear with this approach and the faith in free market forces has been restored with the deflection of the regulation. Here the focus point shifted from the regulation/deregulation of markets to the regulation of human behaviour. In other words, the emphasis is not on regulating the market or removing regulation. It is rather on bringing the market to perfection by regulating human behaviour. Boeckler and Berndt [12] have named this "the post-market neoliberalism" and argued that neoliberalism might have entered into a new phase. According to Boeckler and Bernt [12], "Homo economicus" has been revitalized once again in this approach not only with the unstable effect of practices and experiences that have been spread out socio-technically, but also with the biological engineering of the psychological and neural system of the human body [12].

Behaviouralism, which became prominent based on the observation that humans did not act as claimed by the neoclassical theory of economics, did not make any change in the founding principles of mainstream economics. 
Bigo and Negru[13] have examined publications and presentations made in important academic journals and conferences since 2007 and they have demonstrated that the importance given by economists to mathematic modelling has a tendency to increase, rather than to decrease. This process has brought up to the agenda the revision of mathematical models only within neoclassical economics as well as the revision of approaches used in those models.

However, the basic problem here is to take as a single reality and apply certain mathematical modelling methods in the analysis of economic facts, without examining them much. A more radical criticism about this subject might be made over scientific research principles: These methods and techniques are instruments and as each instrument, they might be convenient for certain circumstances while they might not be for some others. Thus, a more radical reorientation is necessary in the discipline, rather than a moderate revision.

The only development in and after global crisis is growing the prominence of financial regulation. Although there was a consensus reached by a large academia in bringing back financial regulations with macro and micro regulation instruments during the post-crisis period, reforms have been concluded with moderate revisions and the financial sector continued growing after the crisis $[14,15]$.

\subsection{Institutional Economics}

Institutional economists, who established a link between long term changes in production and employment on the one hand and the institutional modifications in economics on the other hand, have developed an alternative approach. Institutional economists place economics within its existing social context and establish the link of today's economic conditions with economy, labour and social history.According to institutional economists, general laws are not helpful guides in understanding the past or forecasting the future; because they neglect the central role of politic and economic institutions in shaping the distribution of resources in society and the development of technology.

Here the main criticism is related to the orthodox theory, where the building stones consist of the restrictions and the objectives of individual units and where politics do not play any role in the economic system.Because according to institutional economics, individuals are partly formed by society and partly by its institutions. If individuals and society are formed on a basis of reciprocity, the forms of society as well as reforms are ongoing processes; neither society nor individuals are stable. Thus, history performs analysis once again. According to Hodgson [16] who defended historical specificities in social sciences, human nature is shaped and constantly reformed by social institutions.

The crisis generally draws the attention on the date it sees as a homogenous data repository. Due to the open nature of economic processes, the source of findings obtained in due time is not homogenous; institutions and behaviours evolve differently in different times and different societies in a non-deterministic manner. Briefly, the historical context is of capital importance [3]. According to Dow and et al. [3], economic principles are not universal. Instead, economic perception depends on the institutional context, which is an outlook of historical changes in reality. Each era has different institutions and different socio-economic systems.

\subsection{Keynesian Economics}

Certain economists advocated that monetary and financial policies implemented during the crisis have stopped the bleeding but have not provided a strong recovery. According to them, a Keynesian crisis is faced together with the insufficiency in aggregate demand, due to the substantial redistribution of income to capitalists and wealthy people since the 1970's [17]. They believe that economic recovery depends on policies that would stimulate aggregate demand and foresee the redistribution of income from wealthy savers to poor and middle classes.

Similarly, Keynesian economics casts important roles to the state in economic stability and growth, beyond financial stability. Keynes appears like a criticism of orthodox economic laws in the macro field. Orthodox economics continued to believe on a version of the Say law where production is made for consumption, and argued that economic crises derived from inefficacious monetary policies. What is necessary and sufficient in the orthodox perspective is an consistent monetary policy. Here when states start once providing liquidity to the banking system, they do not need to make any other intervention or expenditure. On the other hand, Keynes demonstrated that there is no direct tendency towards full employment in macroeconomics and imbedded the Say law in history. Nevertheless, he is faithful to orthodox economics related to the individual (micro) behaviour lying under Say's macroeconomic law. While the new production theory should be based on the non-neoclassical individual behaviour theory, the Keynesian theory has rendered possible to maintain former microeconomics. Since Keynesian economics are deemed appropriate for special depression cases, it has been possible for the former orthodox approach to come back [17].

The 2007/2008 crisis has been considered as such a special situation and led to the recall of the Keynesian intervention. Finally, neoliberal policies have been readopted following poor expenditure and tax policies and then an extreme and unscaled financial market intervention [14].

\subsection{Tendency Towards Classical Political Econoy/Classical Economic Theory}

In the main lines of classical economics, the function of economic analysis as to reveal the effects of changes in the quantity and quality of the labour force on the rate of growth 
of aggregate output. After 1870, the classical theory of economic development was replaced by the concept of general equilibrium within an essentially static framework [18].

Since the notion of taking a social position in a certain social class has been abrogated together with the marginalist reform in classical political economy after D. Ricardo, economists tended towards the analysis of isolated individuals that took place in market relations. When assuming a social position is being neglected, the distribution of the positional power in society is also being neglected. The positional power associated with social positions is connected with reproduction processes. Finally, it has been argued that tending towards reproduction processes and thus the social position provides a wider perspective for understanding the socio-economic order [19].

This new approach (social ontology), which calls out the inclination from the notion of equilibrium to the notion of reproduction and from methodological individualism to social classes, especially provides an efficient analysis for explaining the "power" that comes to the forefront in discussions made following the global crisis [19]. In the analysis developed by Lawson [20] the structure that comprises the connections between social positions such as the land owner, capital owner and worker is called the social structure. The social structure reveals the positional power, which is the set of rights and obligations connected with each position.

The classical school, which assumes that prices can be measured objectively by looking at the processes of reproduction, configures an economic theory that is consistent with various institutional structures and here the market is only one of those many institutions. For example, the internal structure of a firm that is composed of many social positions, is a socio-economic structure which removes to a considerable extent the market change relations. Lawson's concept of social position might also be used for explaining the notions of debt and credit, which constitute a certain form of rights and obligations that are vital for understanding the global financial crisis [19].

\section{The Crisis and Public Finance}

In neoclassical theory, the role of the state in general and in crisis in particular structured in basis of standard normative assumes. In traditional neoclassical economics, equilibrium has a very strong normative thrust. In theory's equilibrium represented a harmonious and spontaneous reconciliation of conflicting economic self-interests; it required no interventions of any "visible hands" like state. According to the theory, the role of the state is securing the key institutions of private property and competitive markets beside state's provision as well of public goods that cannot be provided by private markets [4].Neoclassical explanations usually deny that cycles are intrinsic to capitalism and argue instead that "outside forces" cause them. The most frequently theorized external cause of capitalism's cycles has been the intrusion of government into the working of mostly private enterprises and free markets [4].

Whereas, starting from the United Kingdom, economic history provides examples of the strong connection established between the state and the economic system. According to Sayar [6], although Adam Smith opposed strongly to the mercantilist approach which converted free trade to colonisation, there is no doubt that economists, who leagued together around J. Bentham in the 1860's, have produced a doctrine of imperialism. Investigations made on colonisation have a bigger potential than the "laissez-faire" approach for offering a solution faced by the British economy in what concerns capital accumulation, investment opportunities and the expansion to new markets [6]. Thus, economic liberalism has rendered indispensable to act together with the state. Although the biggest fanatics of "laissez faire" accepted the necessity of the state for the resolution of problems created by industrialisation as well as by the fact of urbanisation it has triggered [6].

Keynes's structural analysis of how capitalism worked explained why and how capitalism's basic structures could cause economic behaviour that produced an unacceptable economic equilibrium. Keynes and his followers showed how the state could correct or offset the effects of those structures to yield a better equilibrium with less unemployment and more output [4].

In other words, the role of the state in economy can be explained spatially and historically with the whole of related social relations; in response to neoclassical economics that take as data the structure, facts and functioning of the past, the status quo, the established system. Social relations comprise material and immaterial relations. The role of the state in what regards the material production relations of society is related with the nature of capitalism. In a society where capitalist production relations are valid, the state maintains the basic functioning mechanism of capitalism but it also has to satisfy certain human requirements that are not met in the market system [21]. As experienced during the global crisis, the state which allocates important resources for the first function is not or cannot be generous to the same degree for the second function. This is a fact named as the "financial crisis of the state" in Marxist economics while it is denominated as the "fiscal cliff" in today's U.S.A. The fact that the state cannot intervene to social risks nowadays causes impoverishment and unfair income distribution. This function of the state is vital not only for the financial stability of the capitalist system, but also for its social sustainability.

When considered from this point of view, the state which is the actor of the discipline of public finance, appears as the actor of the whole social and economic mechanism in opposition to what is foreseen by the neoclassical theory. In global crisis, governments took on major roles in managing the business cycle as in the depression of 1929. Marxist economic schools that provide comprehensive analysis about the role of the state in the capitalist system have gained popularity together with the crisis. Also this theory argues 
that the state has to fulfill important duties for the sustainability and legitimacy of the system, due to the nature of the capitalist system prone to crisis.

\section{A New Perspective to Economics}

From classical economics until today, economics ceased to be a theory concerning wealth and became a "theory of preferences aimed at maximization". This means that human activity is perceived totally as "economic". In such an environment, it has been thought that principles disclosing market behaviours can explain the totality of human behaviours.In this context, man can be reduced to homo "economicus" and society can be reduced to market. This limited assumption has gained importance so as to determine politics as well as economic thought [22].

This reductionist approach of neoclassical economics refers to a divergence from its power to explain the economic reality in many aspects. The theory of neoclassical economics reduces self-seeking, rational, maximizing human behaviours to mathematical patterns. Yet human life is too complex, multi-dimensional and contradictory to fit into such patterns [23]. While the theory is based on individualist preferences, it is well known that human life does not only consist of individual behaviours and that social preferences also play an important role [23].

Adam Smith believed that an economic system established in the framework of pecuniary advantage motivation would be liberating in two ways. First of all, this system would lead to an important increase in wealth and remove the dominance of nature on mankind. Secondly, this system would automatically create an order where people would be able to meet their needs without having to use force on humans. At this point, the problem is to what extent can an economic system based on self-interest maximization motivation establish the equilibrium in resource allocation so as to exclude the fact of power [22].

In his book entitled "Risk Uncertainty and Profit", Frank Knight determined maybe better than all economists that no human behaviour was intrinsically economic. According to him, motivations that orient behaviours were not only economic and that especially goods and services were requested not only for their own characteristics but also for the symbol values they involved. These symbol values were determined by social relations [25]. Further to that, Knight argued that the "laissez-faire" individualism which took human preferences as data ignored the conflict of interest in society. According to him, the laissez-faire individualism had never been implemented in any society, nor had it been desired. Furthermore, it had no theoretical validity within the characteristics of the real world. According to Knight, one of the most important reasons of this phenomenon was that uncertainty- which was the main characteristic of the real world-was not permitting a system to function automatically, as mentioned in the theory. To the extent that it led to profit and loss, uncertainty caused that the system functioned in favour of some and to the detriment of others and thus created socially undesired consequences. In conclusion, the system was not functioning so as to exclude the fact of power, just as Adam Smith thought it would be. Uncertainty appeared as the source of power, so as to come into conflict with all social objectives [25].

Similarly, the neoclassical theory focuses on the equilibrium and the result, not on the context, process and evolution, which are important from the social and individual points of view. However, depending on different persons, situations and choices, individual preferences also differ and they reach different results and equilibriums [23]. Actually, the big inequalities of the capitalist economy and the power imbalances they create are the most important interventions that prevent the "free functioning of markets" which is a principle hardly defended in the theory of Neoclassical economics [23]. It is a historical fact that income and wealth distribution have been negatively affected by monopolisation which followed the first development process of capitalism as well as by extensive privatisations that created monopolies in recent years.

Nowadays the mentioned balances of power have become dominant factors that determine economy policies. While issues such as the growing financial sector, debts and interests come into prominence in today's economies, these economies testify to tendencies that are inconsistent with the forecasts of the theory, such as developing countries that finance the debts of the U.S.A. In spite of the abrogation of financial sector regulations starting from the beginning of the 1980 's, the state interventions made during the 2008 global crisis and a large consensus reached on the necessity of regulations during the post-crisis period, very few progress has been made in practice and this situation might also be explained in this framework. Hence, state interventions aimed at transferring resources to the financial sector have created important budget imbalances and thus national debt burdens have reached historically high levels. These interventions have been legalized with the justification that "sustaining growth" would bring an increase in welfare for all the social classes that have suffered from financial burdens. Thus, neoclassical economics -which finds the solution of many problems in growth, including income distribution- continued its dominance also during the post-crisis period.

Yet, the methods of the neoclassical approach might not be very appropriate for enlightening the social material, due to the nature of social reality. Models using mathematical methods are closed systems where the world is analysed based on atomistic individuals isolated from each other. Whereas social phenomena are not isolated from each other and there are important internal connections between them. If they reveal naturally a processual/evolutionary development, they are constantly transformed with practice and they cannot be atomistic. Moreover, mathematical modelings that are based on assumptions might, not always but to a large extent, damage complex facts within real social systems.

Certainly, the history of neoclassical economic doctrines provided some economic tools which enabled us to evaluate economic phenomena with a new perspective. In fact there 
are modern economists within the neoclassical synthesis such as Paul Samuelson, who perceive economics as a science that evolves together with history and traditions. The problem is that neoclassical economics are being imposed as a single model in the recent years. Since economic facts occur under the influence of sociology, politics and history, the approach to be adopted is a theoretical, methodological plurivocality and an interdisciplinary approach. The impacts of institutional and cultural factors on economic facts might be conceived with qualitative analyses [26].

In this respect, it is a necessity that neoclassical economics discusses its assumptions and framework and makes an expansion to social sciences. In this context, philosophical inputs might have a higher explanatory power. Especially ontology might make important contributions at this point, since it is the branch of philosophy which studies the structure or nature of economic phenomena. Social ontology, which reveals the nature of economic phenomena, might play a role in decreasing the nonconformity between mathematical methods and social facts [9].

Due to the fact that the studies on the history of thought are especially restricted in the discipline of public finance, the discipline cannot produce the knowledge that would enable it to come to the fore as an integral network of theories [27]. Since the discipline of public finance never investigates the ontology of the subject of study, it has been based on a formal state perception [28]. This situation was the result of the tendency to understand society as a set of economic activities while the political philosophy was getting deteriorated. Here economic facts had been treated so as to comprise social facts. In other words, the idea of a society functioning independently from politics according to its own rules had been predominating. Economic schools had made use of this idea adopted from Adam Smith by exercising a mathematical modelling they had developed at an unprecedented pace. As a result, they had caused the inefficiency of alternative approaches that were trying to orient economic processes by using political will. [8]. This phenomenon determines the present-day environment of economic thought related to state intervention.

The approaches of heterodox economists, who are aimed at bringing the financial sector of the economy to manageable dimensions and supporting it from the demand-side, might be theoretically examined and their applicability might be analysed. Furthermore, theories which approach economics from the expenditure-side, rather than equilibrium markets, might also contribute to those discussions. For example institutional economists refer to institutional changes in the economy, due to the long-term modifications in employment and production. Thus, the theory places economy into its existing social context and enriches our knowledge by establishing the link between today's economic conditions and economic history, social history as well as labour history.

It is evident that economic theories conceptualize the realities of their times. Every theory reflect in dominant way of production and social organization shaping with it as well as individual behaviour related to this pattern [29].

Who argued what in theories, why and under which conditions; what are the dynamics and causations lying under them? In order to understand society and the economic dimension of society, we shall have a theory on society and social change. Thus theories shall be historical and spatial: We shall add time, space, philosophical and ethical thoughts to theories. In this respect, the history of economic thoughts is of capital importance. Since the $17^{\text {th }}$ century, there is a rich literature in the analysis of social reality. Economic concepts have taken place in flexible forms of social analysis for the French philosophers of the $17^{\text {th }}$ century and the British economists of the $18^{\text {th }}$ century. Considering this information, it would be appropriate to approach each national economy by developing authentic theories that are in line with its past and present characteristics.

As Marc Blaug [18] put it in theEconomic Theory In Retrospect "the history of economics reveals that economists are as prone as anyone else to mistake chaff for wheat and to claim possession of the truth when all they possess are intricate series of definition or value judgements disguised as scientific rules. There is no way of becoming fully aware of this tendency except by studying the history of economics".

\section{Conclusions}

The crisis indicates the hazardaous of becoming one economic theory dominant. Thus, we shall be much more close to the point that the discipline of economics need to be in connected more with other theories as well as other disciplines.

The crisis brought up to the agenda some facts that are not contained in the neoclassical economic theory with regards to the discipline of public finance. The crisis once more opened for discussion the inefficiency of public finance, which is analysed on the basis of minimizing state intervention to markets in neoclassical economics. Thus, the theory of neoclassical economics, which leans on "laissez faire", cannot establish a basis for explaining the state interventions to the economy.

Yet, the increasing intervention of the state throughout history is related to the achievement of conditions concerning the reproduction of the capitalist system itself and at this point the way the state forms is determined socially, politically as well as historically matters.

\section{Acknowledgements}

I am grateful to İzzettin Önder and Ahmet Uzun for constructive suggestions to improve this template. 


\section{REFERENCES}

[1] Robinson, J, Economic Philosophy, Second printing, Aldine Pub. Co., Chicago, 2007.

[2] Palma, G. "The revenge of the market on the rentiers, Why neo-liberal reports of the end of history turned out to be premature", Cambridge Journal of Economics, Vol. 33, No.4, 829-69, 2009.

[3] Dow, A. And Dow, S., "Economic history and economic theory: The stables approach to economic development", Cambridge Journal of Economics, Vol.38, No.6, 1339-1353, 2014.

[4] Wolff, R.D., S.A. Resnick, Contending Economic Theories, The MIT Press, Cambridge, 2012.

[5] Balseven, H. ve F. Ercan, Kriz ve Türkiye Aşınan Teoriler, Siyasal Kitapevi, Phoenix Yayınevi, Ankara, 2013.

[6] Sayar, A. G. İktisat Metodolojisi Tarihine Bir Katk1: 1950'lerde Londra İktisat Okulunda Gözlemlenen 2 'Genç Türk Hareketine Dair Bazı Tespitler, 58-74, içinde Iktisat Metodolojisi ve Düşünce Tarihi Yazıları, Ötüken, 2. Basım, İstanbul, 2011.

[7] Yeldan, E., “İktisat ve İktisatçı Nereye?”,Toplum ve Bilim, Kiş, 95, 147-150, 2002/2003.

[8] Buğra, A., İktisat siyasete karşı, Toplum ve Bilim, Kıș, 95, 23-42, 2002/2003.

[9] Lawson, T., Really Reorienting Modern Economics, INET Conference, King's College, 2010

[10] Fama, E., "Efficient capital markets: A review of theory and empirical work", Journal of Finance, May, 1970.

[11] Minsky, H. P., The Financial Instability Hypothesis, Levy Economics Institute, Working Paper No:74, 1992.

[12] Boeckler, M. and C. Bernt, "Geographies of circulation and exchange III: The great crisis and marketization after markets", Progress in Human Geography,Vol.37, No.3, 424-432, 2013

[13] Bigo, V. and I. Negru, "Mathematical modelling in the wake of the crisis: a blessing or a curse? What does the economics profession say?, Cambridge Journal of Economics, Vol.38, No.2, 329-347, 2014.

[14] Balseven, H., "The Meaning of the disputes on regulation policy after 2007/2008 crisis in the content of economic governance", Critical Governance Conference, The
University of Warwick, UK, 13th \& 14th December 2010.

[15] Balseven, H., "The political economy of financial regulations policies following the global crisis", International Journal of Economics and Financial Issues, Vol.6, No.2, 607-616,2016.

[16] Hodgson, G., How Economics Forgot History, Routledge, London and New York, 2001.

[17] Friedman, G., "The crisis and the economists: a guide to the perplexed", Labor History, Vol.51, No.3, 345-362, 2010.

[18] Blaug, M., Economic Theory in Retrospect, Fifth edition, Cambridge university press, Cambridge, 2005.

[19] Martins, N. O., "Interpreting the capitalist order before and after the marjinalist revolution", Cambridge Journal of Economics, Vol.39, No.4, 1109-1127, 2015.

[20] Lawson, T, "Ontology and the study of social reality: emergence, organisations, community, power, social relations, corporations, artefacts and Money", Cambridge Journal of Economics, Vol.36, No.2, 345-385, 2012.

[21] Arın, T, İktisatta Devlet ve Devletçilik, Iktisadın Dama Taşları, İFMC İktisat Dergisi, 39-57, 2003.

[22] Buğra, A., "İktisat ve Ahlak”, Toplum ve Bilim, 41, Bahar, 9-41,1988.

[23] Bulutay, T., "İktisat kuramı, eğitim v egelir bölüşümü”, İktisat Issletme ve Finans, Vol.21, No.241, 8-65, 2006.

[24] Knight, F. Risk Uncertainty and Profit, New York: Harper and Torch, 1965.

[25] Buğra, A., Íktisatçılar ve insanlar, İletişim yayınları, 7. Baskı, İstanbul, 2010.

[26] Boratav, K., “İktisat öğrencileri itiraz ediyor”, Solportal, 13 Mayıs 2014

[27] Oyan, O., Kamu Maliyesi ve Türkiye'de Maliye Eğitimi, içinde Dışa Açılma ve Mali Politikalar Türkiye: 1980-1989, Verso yayınları, Ankara, 311-330, 1989.

[28] Ördek, A, “1980'den sonraTürkiye maliye disiplininde kuramsal gerilimler: Türkiye maliye sempozyumu tebliğleri çerçevesinde bir değerlendirme", içinde Kriz ve Maliye Düşüncesinde Değişim, İzzettin Önder'e Armağan, edit. A. Pınar, A.H.Köse, N. Falay, SAV Yayınları, İstanbul, 2011.

[29] Önder, İ., Thorstein Veblen: Çok Yönlü Bir İktisatçı, içinde Thorstein Veblen Kullanım Kılavuzu, edit by: Ahmet Öncü, TMMOB, Habitus Kitap, İstanbul, 2015, 55-79. 